Winter 2012

\title{
Citizenship and Marriage in a Globalizing World: Multicultural Families and Monocultural Nationality Laws in Korea and Japan
}

\author{
Erin Aeran Chung \\ Johns Hopkins University, Department of Political Science, echung@jhu.edu \\ Daisy Kim \\ Johns Hopkins Univdersity, Department of Political Science, dkim106@jhu.edu
}

Follow this and additional works at: https://www.repository.law.indiana.edu/ijgls

Part of the Civil Law Commons, Comparative and Foreign Law Commons, Family Law Commons, Immigration Law Commons, and the International Law Commons

\section{Recommended Citation}

Chung, Erin Aeran and Kim, Daisy (2012) "Citizenship and Marriage in a Globalizing World: Multicultural Families and Monocultural Nationality Laws in Korea and Japan," Indiana Journal of Global Legal Studies: Vol. 19 : Iss. 1 , Article 8.

Available at: https://www.repository.law.indiana.edu/ijgls/vol19/iss1/8

This Symposium is brought to you for free and open access by the Law School Journals at Digital Repository @ Maurer Law. It has been accepted for inclusion in Indiana Journal of Global Legal Studies by an authorized editor of Digital Repository @ Maurer Law. For more information, please contact rvaughan@indiana.edu.

JEROME HALL LAW LIBRARY

INDIANA UNIVERSITY Maurer School of Law
Blooming ton 


\title{
Citizenship and Marriage in a Globalizing World: Multicultural Families and Monocultural Nationality Laws in Korea and Japan
}

\author{
ERIN AERAN CHUNG* AND DAISY KIM**
}

\begin{abstract}
This Article analyzes how individual and local attempts to address low fertility rates in Korea and Japan have prompted unprecedented reforms in monocultural nationality laws. Korea and Japan confront rapidly declining working-age population projections; yet, they have prohibited the immigration of unskilled workers, until recently in Korea's case, on the claim that their admission would threaten social cohesion. Over the past two decades, both countries have made only incremental reforms to their immigration policies that fall short of alleviating labor shortages and the fiscal burdens of maintaining a large elderly population. Instead, prompted by the growth of so-called multicultural families in each country, the most significant reforms have appeared in nationality laws: Korea's introduction of dual nationality in 2010 and Japan's 2008 reform to grant Japanese nationality to children born out of wedlock to a Japanese father and a foreign mother. While neither country has introduced birthright citizenship to their nationality laws, both sets of reforms target ethnically heterogeneous immigrant women, their bicultural children, or both. This Article seeks to understand how recent reforms to nationality laws in Korea and Japan
\end{abstract}

* Erin Aeran Chung is the Charles D. Miller Assistant Professor of East Asian Politics and Co-Director of the Racism, Immigration, and Citizenship Program in the Department of Political Science at the Johns Hopkins University. She is the author of Immigration and Citizenship in Japan. Unless otherwise noted, all translations are my own.

** Daisy Kim is a Ph.D. candidate in the Department of Political Science at Johns Hopkins University, Baltimore, USA. She is currently a Fulbright IIE junior researcher in Korea for the 2011-12 academic year and was the recipient of the 2011 Korea Foundation Research Fellowships. Unless otherwise noted, all translations are my own.

Indiana Journal of Global Legal Studies Vol. 19 \#1 (Winter 2012)

(C) Indiana University Maurer School of Law 
have challenged long-held conceptions of blood-based belonging and membership.

\section{INTRODUCTION}

Since 1990, Japan's Ministry of Health, Labor, and Welfare and Korea's Ministry of Health and Welfare have issued reports warning of the imminent demographic crises in both countries. Fertility rates had begun to plummet below the population replacement level of 2.1 children per woman since 1975 in Japan and since 1984 in Korea, reaching an all-time low of 1.26 in Japan in 2005 and 1.08 in Korea in $2005 .{ }^{1}$ By 2010 , the percentage of the population aged sixty-five or older reached 23.1 percent in Japan and 11 percent in Korea. ${ }^{2}$ Japan's National Institute of Population and Social Security Research estimates that the working-age population will fall to approximately sixty percent of Japan's total population by 2020 and approximately fifty-four percent by $2050 .^{3}$ The Korean prognosis is not much brighter: the estimated working-age population in South Korea is expected to fall to approximately fifty-four percent by 2050 . In 2001, the United Nations Population Division published a report on replacement migration that estimated that Japan would have to admit approximately 647,000 immigrants and that Korea would have to admit 129,000 immigrants annually in order to alleviate labor shortages and the fiscal burdens of rapidly growing elderly populations. 4

The Korean and Japanese governments have attempted to tackle the problem of declining birth rates by providing subsidies for childcare

1. Kor. Stat. Info. Service, Vital Statistics, KOSIS (2010), http://kosis.kr/nsieng/ view/stat10.do (enter "2005" into "Search Period" for Korean fertility percentages); Standardized Vital Rates and Reproduction Rates, 2011 JAPAN STAT. Y.B. (Ministry Internal Aff. \& Commc'ns), available at http://www.stat.go.jp/english/data/nenkan/backdata/1431 02.htm.

2. Kor. Stat. Info. Service, Population, Household, KOSIS (2010), http://kosis.kr/ eng/database/database_001000.jsp?listid=B\&subtitle=Population,\%20Household (citing the percentage of those who are sixty-five years and older in Korea in 2010) (open "Population Projections and Summary Indicators for Korea"; enter "2010" into "Search Period"); Stats. Bureau, Preliminary Sample Tabulation of the 2010 Population Census of Japan Released, MINISTRY INTERNAL AFF. \& COMMC'NS (Sept. 15, 2011), http://www.stat.go.jp/english/info/ news/1932.htm.

3. Nat'l Inst. of Population and Soc. Sec. Research, Population Projections FOR JAPAN: 2001-2050, at 3 (2002).

4. U.N. DEP'T OF ECON. \& SOC. AFFAIRS, REPLACEMENT MigRaTion: IS IT A SOLUTION To DeClining AND AGEING PopUlations?, U.N. Doc. ST/ESA/SER.A/20, U.N. Sales No. E.01XIII.19 (2001), available at http://www.un.org/esa/population/publications/migration/ migration.htm (referring to the period 2000-2050 for the constant age group, 15-64 (Scenario IV in Tables 21 and 22)). 
(both Korea and Japan), tax breaks for families with more than two children (Korea), and guidelines for businesses to create more familyfriendly policies (Japan). ${ }^{5}$ Neither country, however, has opened its borders to immigration at the level necessary to alleviate labor shortages. Instead, both countries have made only incremental reforms to their immigration policies that largely prohibit permanent immigrant settlement. ${ }^{6}$ To be sure, the foreign populations in Korea and Japan have grown exponentially over the past few decades, from slightly over 210,000 in 2000 to over 990,000 in 2009 in Korea and from approximately 850,000 in 1985 to almost 2.2 million in 2009 in Japan. Nevertheless, their numbers make up less than two percent of the total population in each country, which is well below the recommended thirty percent outlined in the aforementioned UN report on replacement migration.

While the national governments in Korea and Japan have aimed to alleviate their respective demographic crises by creative incentives for married couples to have more children, local governments, businesses, and civil society actors, especially in the rural areas, have focused their attention on finding spouses for unmarried, largely male, adults. In Korea, the 1992 treaty to establish diplomatic and trade relations between Korea and China opened the door to arranging marriage meetings between Korean men and ethnic Korean (Chosunjok) women from China that were brokered by local government officials and agricultural associations in many rural areas. ${ }^{8}$ After 1999 , with the deregulation of the marriage industry in Korea, international marriages expanded to include migrants from Southeast Asian countries and

5. YOON-YOUNG CHO, GIHON YEOSEONG UI CHULSAN GWA NODONGGONGGEUP:

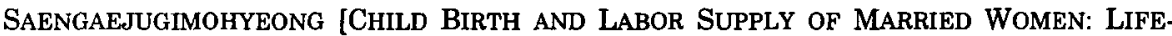
CYCle MODEL 26-31 (2006); HYUN-SEUNG LEE \& HYUN-JIN KIM, NEULGEO GA NEUN DaehanminguK [Aging Korea] 102 (2003); Robert L. Clark et al., Population Decline, Labor Force Stability, and the Future of the Japanese Economy, 26 EUR. J. POPULATION, 222 (2010).

6. Dong-Hoon Seol \& John D. Skrentny, Why Is There So Little Migrant Settlement in East Asia?, 43 INT'L MIG. REV. 578, 579 (2009).

7. CHULIPGUK OEguKIN-JEONGCHAEK TONGgYaE-YeONBo [ANNUAL STATISTICAL REPORT FOR POLICIES ON IMMIGRATION AND FOREIGNERS] 259 (2009); Ministry of Internal Affairs \& Commc'ns, Historical Statistics of Japan, STATS. BUREAU, http://www.stat.go.jp/ english/data/chouki/index.htm (last visited Nov. 6, 2011) (click on "Chapter 2: Populations and Households"; scroll to "Migrants" subheading for Excel sheets containing statistical data on "Foreigners who Legally Entered Japan by Status of Residence" for the years "1954-1989" and "1990-2004" respectively) [hereinafter Historical Statistics of Japan].

8. Hye-Kyung Lee, International Marriage and the State in South Korea: Focusing on Governmental Policy, 12 CITIZENSHIP STUD. 107, 110-11 (2008). We apply the McCuneReischauer romanization to Chosunjok, which appears as Joseonjok, using the official South Korean romanization system. 
Russia. ${ }^{9}$ By 2009, the number of so-called marriage migrants in Korea had reached over $125,087 .{ }^{10}$ In Japan, local governments in depopulated rural areas began to actively recruit migrant brides from the Philippines, China, Taiwan, and Korea through arranged meetings and private brokers from the $1990 \mathrm{~s}^{11}$ This trend departed from individual efforts by Japanese men to find marital and/or sexual partners in Asian countries from at least the 1970s, when the Philippines introduced state-sponsored sex tourism. ${ }^{12}$ By 2009, international marriages made up approximately five percent of all marriages in Japan. ${ }^{13}$

For decades, monocultural ideologies based on the myth of a oneblood nation (tanil minjok in Korean and tanitsu minzoku in Japanese) have undergirded national identity and membership in Korea and Japan. The migration and integration of ethnoculturally heterogeneous brides and bicultural children have not only disrupted monocultural ideologies about nationhood and membership, but they have also presented legal challenges to nationality laws that reflect such ideologies. Questions about how to integrate multicultural families have given rise to the development of multicultural (damunhwa in Korean and tabunka in Japanese) discourses in the public sphere. In Korea, the government took the lead in embracing the integration of multicultural families as official national policy, while, in Japan, attempts at multicultural policy have been contained within local communities. Such different approaches toward multicultural families have shaped how each country has responded to pressures from different segments of society to revise monocultural nationality laws.

Compared to the incremental reforms to immigration policies in Korea and Japan, the growth of so-called multicultural families that have emerged from marriage migration have prompted significant reforms to each country's nationality laws. In 2010, Korea's National Assembly passed a bill to allow dual nationality, which went into effect

9. Id. at 112 .

10. ChulipguK OEguKIn-JEONGCHAEK TONGgYAE-YeONBO [ANNUAL STATISTICAL REPORT FOR POLICIES ON IMMIGRATION AND FOREIGNERS], supra note 7, at 257.

11. Hiroo Kamiya \& Chulwoo Lee, International Marriage Migrants to Rural Areas in South Korea and Japan: A Comparative Analysis, 81 GEOGRAPHICAL REV. JAPAN (SPECIAL ISSUE) 60, 64-65 (2009).

12. Cf. Nobue Suzuki, Transgressing "Victims": Reading Narratives of "Filipina Brides" in Japan, 35 CRITICAL ASIAN STUD., 399, 402-03 (2003) (referring to a Japanese village that brought in six Filipina hanayome [brides] for reproductive purposes through a bilateral agreement with a city in the northern Philippines); id. at 405 (noting the position put forth by the Filipina representative at the United Nations Women's Conference in Nairobi in 1985 that marriages between Filipinas and Japanese men are an "extension of prostitution").

13. Vital Statistics of Japan, MINISTRY HEALTH, LAB., \& WELFARE, http:/www.mhlw.go.jp/ toukei/saikin/hw/jinkou/suii09/marr2.html (last visited Feb. 16, 2012). 
in 2011.14 In Japan, the Supreme Court ruled in 2008 that children born out of wedlock to a Japanese father and a foreign mother should be granted Japanese nationality. ${ }^{15}$ While neither country has introduced birthright citizenship to their nationality laws, both sets of reforms target ethnically heterogeneous immigrant women (Korea) and their bicultural children (Japan), thereby challenging the core principles of nationality laws premised on claims of ethnocultural homogeneity.

This Article analyzes how gendered migration has challenged longheld conceptions of blood-based belonging and membership and subsequently created a political opening for revisions to nationality laws. We thus seek to fill the theoretical gap between gendered migration and citizenship by bringing to the fore the tensions between the need to address demographic challenges, the intent to maintain and control membership based on ethnocultural homogeneity, and the policy outcomes that have undermined such intent. The following section analyzes the relationship between citizenship and identity, especially how notions of blood-based membership interact with the rights and duties sanctioned by the state through formal citizenship. The subsequent sections examine patterns of immigration to Japan and Korea in the past few decades with special attention to the phenomenon of marriage migration. Finally, we turn our attention to how marriage migration and, especially, how the growth of so-called multicultural families has prompted reforms to nationality laws in Japan and Korea.

\section{MARRIAGE MigRation, NATIONHOOD, AND CITIZENSHIP}

In recent years, scholars have noted the absence of sufficient attention to explicating the relationship between gender and migration. Further, they argue that migration is becoming increasingly feminized as more women than ever before navigate the South-North divide in search of better opportunities in wealthier foreign countries. ${ }^{16}$ Migrant women from the global South have taken on positions as factory workers in industrial sectors, such as textiles and electronics, as primary caregivers for children and the elderly, and as domestic

14. Kim Rahn, S. Korea to Allow Dual Citizenship from January, Korea Times (Dec. 23, 2010, 7:21 PM), http://www.koreatimes.co.kr/www/news/nation/2011/04/117_78536.html.

15. Supreme Court Finds Discrimination Against Children Born Out of Wedlock Unconstitutional, 21 WOMEN'S ASIA 32, 32 (2008).

16. See generally StePhen CASTLES \& MARK J. MilleR, THE AGE OF MigRation (4th ed. 2009); INTERNATIONAL MIGRATION OF WOMEN (Andrew R. Morrison et al. eds., 2008); Eleonore Kofman, GENDER AND INTERnational Migration IN EUROPE (2000); Katharine M. Donato et al., A Glass Half Full? Gender in Migration Studies, 40 INT'L MIG. REV. 3, 3 (2006). 
workers in the private homes of upper- and middle-class families in regions as far as the Middle East, Western Europe, and Southeast and East Asia. With the feminization of migration, scholars and activists have brought attention to the growing prevalence of sex trafficking and prostitution as many migrant women are lured and oftentimes forced against their wills into laboring in the sex industries. Finally, the next stage of research on gendered migration focuses on female migration as reproductive labor in the roles of wives and mothers.

Studies of migrant women demonstrate the eclectic ways in which migration is gendered. ${ }^{17}$ The largest body of literature on female migration focuses on the gendered, structural, and individual causal factors behind the processes of migration, as well as work-related concerns specific to female migrant workers, such as maternity leave and low wages. This literature tends to center on the industries dominated by female workers, such as domestic work, care work, and sex work. ${ }^{18}$ The second body of literature problematizes the links between female migration and sex trafficking, violence, and abuse against migrant women. ${ }^{19}$ The topics addressed in these studies range from the link between domestic work and sexual abuse by employers, to migrant factory workers who are trapped into prostitution rings, to grassroots women's movements mobilized around the prevention of violence against women.

The smallest, but growing, body of scholarship on female migration concerns the phenomenon of international and transnational marriage,

17. See generally WOMEN, GENDER AND LABOUR MigRATION: HISTORICAL AND GLOBAL PERSPECTIVES (Pamela Sharpe ed., 2001) (considering women's varied experiences with migration, including those in Europe, Australia, Japan, South Africa, and Latin America); WIFE OR WORKER?: ASIAN WOMEN AND MIGRATION (Nicola Piper \& Mina Roces eds., 2003) (demonstrating the linkages between marriage, work, and relocation in the migration of Asian women).

18. See generally ELIZABETH BERNSTEIN, TEMPORARILY YOURS: INTIMACY, AUTHENTICITY, AND THE COMMERCE OF SEX (2007) (exploring the changing landscape of sex work and the blurred boundaries between intimacy and commercial sex); GLOBAL SEX WoRKERS: Rights, RESISTANCE, AND REDEFINITION (Kamala Kempadoo \& Jo Doezema eds., 1998) (examining the experiences of sex workers from the developing world, with a focus on grassroots movements by sex workers, as well as the health issues many sex workers face); Rhacel Salazar ParReñas, Servants of Globalization: Women, MIGRATION AND DOMESTIC WORK (2001) (tracing the life experiences of migrant Filipina domestic workers at the local, transnational, and global levels).

19. See generally anna M. Agathangelou, The Global Political Economy of Sex: DESIRE, VIOLENCE AND INSECURITY IN MEDITERRANEAN NATION STATES (2004) (placing the commodification of sex in the broader global political economy as linked to the position of peripheral states vis-à-vis larger powers); Vidyamali Samarasinghe, FEmale Sex TRAFFICKING IN ASIA: The Resilience of PATriaRChy IN A ChangING WORLD 39-58 (2008) (critiquing the continued existence of patriarchic social structures as a main driver of large-scale sex trafficking in Nepal, Cambodia, and the Philippines). 
whereby women from underdeveloped countries are recruited by individual and local actors to marry men from wealthier countries, often of different ethnic origin. ${ }^{20}$ The push-and-pull factors of this type of migration are manifold: closed-door immigration policies of East Asian countries where marriage is one of the limited routes to legitimate migration, stark regional economic disparities, the downward demographic pressures of advanced industrial countries, a booming and minimally regulated international marriage brokerage industry, the implicit or explicit acquiescence and participation of national and local governments, as well as deep-seated patriarchic values toward marriage.

The dominant debate in the scholarly literature on marriage migration centers on the relationship between marriage and labor. One side of the argument states that marriage-based migration should be considered a form of labor migration, while the other argues that marriage migration is singularly distinct from labor migration, as it involves intangible factors such as love and romance. ${ }^{21}$ Such a debate speaks to a broader debate about the role of women's agency in the migratory process and the question of whether migration for a majority of women is a choice or forced upon them by myriad economic and social circumstances. ${ }^{22}$ However, this focus on the relationship between marriage and work obscures the link between family membership and national membership, as acquired through marriage. In other words, the literature has under-examined how marriage migration intersects with conceptions of family, nationhood, and membership.

Building on recent scholarship on transnational marriages and gendered migration, this Article proposes that marriage migration and the subsequent emergence of so-called multicultural families (foreign spouses and their bicultural children) have disrupted existing understandings of nationhood, citizenship, and race and ethnicity that have long been associated with the family unit in putatively homogenous societies. Unlike migrant labor, immigrants who enter a country as spouses of nationals are necessarily permanent settlers who must be incorporated into both a given family unit and the larger receiving society. Because their permanent settlement involves not only

20. See generally CROSS-BORDER MARRIAGES: GENDER AND MOBILITY IN TRANSNATIONAL ASIA (Nicole Constable ed., 2005) (presenting a cross-regional survey of international marriages, which includes discussion on how some use the institution of marriage as an economic opportunity); MARRIAGE, MIGRATION, AND GENDER (Rajni Palriwala \& Patricia Uberoi eds., 2008) (examining how marriage strategies facilitate transnational migration, as well as the fluid boundaries between matchmaking and trafficking).

21. MARRIAGE, MIGRATION, AND GENDER, supra note 20 , at 34 .

22. Id. 
the incorporation of individual migrant adults but also the formation of family units that fit neither the "foreign" nor "single-blood native" categories, they problematize long-held conceptions of both familial and national membership based on blood-purity and descent.

Grassroots efforts to redefine national and social membership combined with state policies aimed at maintaining social cohesion have produced "multicultural" discourses and policies in Japan and Korea. ${ }^{23}$ Although both countries employ the same set of Chinese characters in their respective translations for the term "multiculturalism,"24 their divergent symbolic significance and applications offer an important window into the distinct approaches taken by each country in managing diversity. Whereas "multicultural society" in Korea signifies a broadened definition of Korean national identity to include specific categories of non-Korean immigrants, "multicultural coexistence" in Japan has further narrowed conceptions of Japanese national identity, separating ethnic Japanese (Nikkei) foreigners from "mixed-blood" nationals.

\section{A. Patterns of Immigration to Japan}

Japan's immigration history can be divided broadly into three categories: (1) colonial migration from the early twentieth century to the immediate post-World War II period, (2) refugee and "skilled" migration in the late 1970 s to early 1980 s, and (3) unskilled labor migration from Asia and Latin America from the late 1980s to the present. ${ }^{25}$ Although Japanese employers and officials played important roles in recruiting immigrants-forcibly for a subsection of colonial migrants from 1939Japan's borders were officially open only for the first wave of immigration when Japan was a colonial power with territories that included Formosa, Korea, southern Sakhalin Island, the Kwantung Leased Territory on the Liaotung peninsula, and Japanese mandate islands of Micronesia. ${ }^{26} \mathrm{By}$ the end of World War II, more than two million colonial subjects, primarily from the Korean peninsula, were

23. Erin Aeran Chung, Korea and Japan's Multicultural Models for Immigrant Incorporation, 41 KOR. OBS. 649, 650 (2010) [hereinafter Korea and Japan's Multicultural Models for Immigrant Incorporation].

24. 多文化 literally means "multiple or many cultures."

25. See generally ERIN AERAN CHUNG, IMMIGRATION AND CITIZENSHIP IN JAPAN 144-54 (2010); HIROSHI KOMAI, MIGRANT WORKERS IN JAPAN 15-22 (Jens Wilkinson trans., Kegan Paul Int'l Ltd. 1995) (1993); YoKo SELLEK, MIGRANT LABOUR IN JAPAN (2001).

26. Edward I-te Chen, The Attempt to Integrate the Empire: Legal Perspectives, in THE JAPANESE COLONIAL EMPIRE, 1895-1945, at 241 (Ramon H. Myers \& Mark R. Peattie eds., 1984). 
residing in Japan. ${ }^{27}$ Approximately two-thirds of this population was repatriated during the process of decolonization, and by the end of the American Occupation of Japan in 1952, Japan implemented strict immigration and border controls to prevent the mass influx of former colonial subjects. ${ }^{28}$ Yet, in spite of these controls, with unstable conditions in the Korean peninsula following Korea's liberation from Japan in 1945 and escalating to the Korean War in 1950, illegal immigration to Japan, largely by former repatriates to the Korean peninsula, became a formidable problem during this period, as Tessa Morris-Suzuki documented in a path-breaking study of this first wave of immigration. ${ }^{29}$ Nevertheless, less than 700,000 foreigners resided in Japan by the end of the occupation in $1952 .{ }^{30}$

Between the end of World War II and the 1960s, Japan's emigrant population well exceeded its immigrant population, with over two million Japanese migrants settled in North and South America and, to a lesser extent, in Japan's former colonies in Asia. ${ }^{31}$ Indeed, it was not until 1974 that the Japan Emigration Service, a semiofficial organization affiliated with the Ministry of Foreign Affairs that managed the recruitment and promotion of emigration to Latin America, was replaced by the Japan International Cooperation Agency, marking the dissolution of Japan's official emigration programs to Latin America. ${ }^{32}$ Although Japan experienced labor shortages in the 1960s similar to those in other industrialized countries, Japanese officials and corporations did not import foreign labor, opting instead to automate production, shift production abroad, and tap into alternative sources of

27. MaRK E. CaPRio, Japanese Assimilation Pólicies in Colonial Korea: 19101945, at 93 (2009).

28. See generally TESSA MORRIS-SUZUKI, BORDERLINE JAPAN: FronTIER CONTROLS, Foreigners AND FrontIER CONTROLS IN THE POSTWAR ERA (2010) (reinterpreting postwar Japanese immigration policies, in which the Cold War context is critical in explaining Korean migration in and out of Japan during the postwar period).

29. Id.

30. See Yoshio MoRITA, SUJI GA KATARU ZAINICHI KANKOKU CHOSENJIN NO REKISHI [HISTORY OF KOREAN RESIDENTS IN JAPAN THROUGH STATISTICS] (1996).

31. Recommendations of Overseas Emigration Council Future Policy Regarding Cooperation with Overseas Communities of Nikkei, MINISTRY FoREIGN AFF. JAPAN (Dec. 11, 2000), http://www.mofa.go.jp/policy/emigration/Nikkei.html; MINISTRY oF FOREIGN AFFAIRS OF JAPAN, ANNUAL REPORT OF STATISTICS ON JAPANESE NATIONALS OVERSEAS (2010), available at http://www.mofa.go.jp/mofaj/toko/tokei/hojin/10/pdfs/1.pdf.

32. History, JAPAN INT'L COOPERATTON AGENCY, http://www.jica.go.jp/english/about/ history/index.html (last visited Feb. 19, 2012); Section 5: One-Hundred Years of Governmentendorsed Emigration, Diplomatic Bluebook 1985, MINISTRY ForEIGN AFF. JAPAN, http://www.mofa.go.jp/policy/other/bluebook/1985/1985-3-5.htm (last visited Feb. 20, 2012). 
domestic labor such as women, students, the elderly, and rural migrants. ${ }^{33}$

The second wave of immigration in the 1970 s to early $1980 \mathrm{~s}$, therefore, did not represent responses to labor shortages. Rather, this wave was made up largely of three unrelated groups. The first and largest group consisted primarily of women from the Philippines, Thailand, South Korea, and Taiwan who were recruited to Japan as "skilled" workers to fill the demand in the so-called entertainment industry. ${ }^{34}$ The number of immigrants with "entertainer" visas jumped from almost 6,000 in 1975 to over 34,000 in 1985 and over 75,000 in $1990 .^{35}$ Most "entertainers" continue to be recruited to work as hostesses in the industry known in Japan as mizu shōbai (water trade, in reference to bars, cabarets, restaurants, and so forth) and as prostitutes. ${ }^{36}$ Other "skilled" workers residing in Japan during this period were generally white-collar professionals, many of them from the United States and Europe. ${ }^{37}$ The children and grandchildren of Japanese citizens who remained in Japan's former colonies, mostly China, made up the second group. Although ethnically Japanese and recognized as Japanese nationals, this relatively small group of "returnees" encountered significant problems of adjustment and discrimination, similar to non-Japanese immigrants. ${ }^{38}$ Finally, refugees from Indochina made up the third group, with more than 10,000 entering Japan with temporary visas between 1979 and $1999 .{ }^{39}$ It should be noted, however, that the Ministry of Justice recognized only a total of 315 refugees out of 3,118 applications between 1981, when

33. See Korea and Japan's Multicultural Models for Immigrant Incorporation, supra note 23 , at 662 .

34. ChUNG, supra note 25, at 149-50.

35. Historical Statistics of Japan, supra note 7.

36. See SELLEK, supra note 25, at 37-38, 160-61. In 1988, the Ministry of Justice revised the application procedures for "entertainer" visas to prevent the entry of "entertainers" whose actual work was in the mizu shöbai and sex industries. See KoMAI, supra note 25.

37. Historical Statistics of Japan, supra note 7; see also Registered Aliens by Nationality and Status of Residence (Permanent Resident, Non-permanent Residents) (1948-2009), MINISTRY INTERNAL AFF. \& COMMUNIC'NS, http:/www.stat.go.jp/english/ data/chouki/02.htm (last visited Feb. 4, 2012) (follow 2-12 "Registered Aliens by Nationality and Status of Residence" hyperlink).

38. JOHN DOWER, EMBRACING DEFEAT: JAPAN IN THE WAKE OF WORLD WAR II, at 48-64 (1999); Roger Goodman, The Changing Perception and Status of Japan's Returnee Children (Kikokushijo), in GLOBAL JAPAN: THE EXPERIENCE OF JAPAN'S NEW IMMIGRANTS AND OVERSEAS COMMUNITIES (Roger Goodman et al. eds., 2003).

39. See Takahashi Koichi, Nanmin mondai ni taisuru nihon no torikumi [Japan's Approach to the Refugee Problem], KOKUSAI MONDAI, Dec. 2002, at 52 (2002); Refugees, MINISTRY FOREIGN AFF. JAPAN, http://www.mofa.go.jp/policy/refugee/japan.html (last visited Feb. 20, 2012). 
Japan ratified the United Nations Convention and Protocol Relating to the Status of Refugees, and 2004.40

By the 1980s, when Japan experienced a second labor shortage, internal sources of labor had been depleted and rising land prices in urban areas triggered a reverse migration to surrounding suburbs. ${ }^{41}$ Furthermore, the expansion of private brokers and intermediaries in Japan and various sending countries actively organized and promoted labor migration to Japan. From the late 1980 s, large numbers of foreign workers entered Japan with tourist visas and overstayed their threemonth limit, establishing a substantial population of undocumented immigrants that grew to a high of 300,000 by 1993.42

In an effort to combat illegal immigration and, at the same time, meet labor demands, the government revised the Immigration Control and Refugee Recognition Act in 1990, setting the foundation for Japan's third wave of immigration. In addition to imposing criminal penalties to employers knowingly hiring undocumented workers, the revision reorganized and expanded visa categories from eighteen to twentyseven. ${ }^{43}$ The most significant of these is the "long-term resident" visa granted exclusively to descendants of Japanese emigrants (Nikkei), up until the third generation, and their families, which allows for unrestricted economic activities. Only four other visa categories permit unrestricted economic activities: special permanent resident, permanent resident, spouse or child of a Japanese national, and spouse or child of a permanent resident. ${ }^{44}$ Although Japan's borders officially remain closed to unskilled labor, the revision further allows precollege and college students as well as "trainees" to work for a limited amount of time. ${ }^{45}$

It was during this last wave of immigration that international marriages began to rise significantly in Japan. Although the vast majority of migrant labor to Japan from the late $1980 \mathrm{~s}$ was male,

40. Petrice R. Flowers, Failure to Protect Refugees? Domestic Institutions, International Organizations, and Civil Society in Japan, 34 J. JAPANESE STUD. 333, 340 (2008).

41. See MORI HIROMI, IMMIGRATION POLICY AND FOREIGN WORKERS IN JAPAN 56 (1997).

42. Org. for Econ. Co-Operation \& Dev. [OECD], International Migration Outlook: SOPEMI 2011, at 294 (2011).

43. The revision, modeled after U.S. immigration laws, made employers who hired undocumented workers and brokers who facilitated their employment subject to a maximum three years imprisonment and fines up to two million yen. See KoMAI, supra note 25 , at 5-6.

44. See generally Takeyuki Tsuda \& Wayne A. Cornelius, Japan: Government Policy, Immigrant Reality, in Controlling Immigration: A Global Perspective 439, 439 (Wayne A. Cornelius et al. eds., 2004).

45. Shutsu nyūkoku kanri oyobi nanmin ninteihō daishichijō daiichikō dainigō no kijun wo sadameru shōrei [Immigration Control \& Refugee Recognition Act], Law No. 79 of 2009, Appended Table 1(3) \& (4) (Japan), available at http://www.japaneselawtranslation.go.jp/ law/detail/?id=1934\&vm=\&re=. 
women from Asian countries came to Japan during this period to fill another shortage: the "bride famine" in rural areas. Some municipal governments of depopulated rural communities recruited so-called migrant brides, largely from the Philippines, China, Taiwan, and Korea, through arranged meetings (miai), miai tours in the sending countries, collaborative arrangements with private brokers, or, in the case of the earliest groups of Filipina brides known as hanayome, bilateral agreements. ${ }^{46}$ From 1975, international marriages involving Japanese men and non-Japanese women began to outnumber those involving Japanese women and non-Japanese men and, among the former, the number of marriages involving Filipina women rose from less than 10 percent in 1990 to over 30 percent in 1995.47 Between 1970 and 2000, the number of international marriages jumped from 0.5 percent of all marriages in Japan to more than 4.5 percent. ${ }^{48}$

\section{B. Patterns of Immigration to Korea}

Korea's immigration history can also be divided into three phases: (1) unofficial, unskilled labor migration from China, South Asia, and Southeast Asia from the late 1980s; (2) officially sanctioned foreign labor migration of predominantly male migrant workers during the 1990s through the Industrial Trainee Program (1993) and the Employment Permit System (EPS) (2004) thereafter; and (3) female marriage migration of foreign women who have been immigrating to Korea for the purpose of marriage since the $2000 \mathrm{~s}^{49}$

Before the first wave of immigration began, Korea was historically a country of emigration, where migration outflows outpaced inflows. The only significant foreign population settled in Korea until this time were Taiwanese nationals known as hwagyo (or huaqiao in Chinese) whose roots in Korea date back to 1882 when Korea and China signed a trade agreement permitting Chinese merchants to own and lease land in

46. Suzuki, supra note 12, at 399, 403-04; WOLFGANG HERBERT, FOREIGN WORKERS AND LAW ENFORCEMENT IN JAPAN 34-36 (1996).

47. Gavin Jones \& Hsiu-hua Shen, International Marriage in East and Southeast Asia: Trends and Research Emphases, 12 CiTIZENSHIP STUD. 9, 12 (2008); Fumiteru Nitta, Kokusai Kekkon: Trends in Intercultural Marriage in Japan, 12 INT'L J. INTERCULTURAL REL. 205, 205 (1988).

48. Vital Statistics of Japan, supra note 13.

49. See generally Timothy Lim, Racing from The Bottom in South Korea?: The Nexus Between Civil Society and Transnational Migrants, 43 ASIAN SURV. 423 (2003) (examining the history of transnational labor migration in South Korea); see also Lee, supra note 8 (analyzing the historical evolution of international marriages in South Korea). 
Korea's treaty ports. ${ }^{50}$ During the Japanese colonial period (1910-45), floods of Korean emigrants left for Japan and Manchuria often as conscripted labor, students, and independence fighters. ${ }^{51}$ Although it was not official emigration policy, in the 1960 s and 1970 s, smaller numbers of Koreans left for the United States, Germany, and the Middle East, mostly as students and guest workers, especially nurses and miners in the case of Germany, and as construction workers to the Middle East. ${ }^{52}$ By the late 1980s, foreigners in Korea consisted largely of native-born Chinese residents (hwagyo), foreign spouses of Korean nationals (mostly men from the United States due to long-term U.S. military presence), and a smaller contingent of white-collar professionals. ${ }^{53}$

In the late $1980 \mathrm{~s}$, the Korean economy began to experience acute labor shortages across many of its industries, especially in the manufacturing, production, and services sectors. To address these shortages on an as-needed basis, foreign workers were unofficially permitted to enter through a "wink-and-nod" approach made possible in part by the lobbying of the powerful Korean Federation of Small Businesses, where Korean authorities implicitly turned a blind eye to foreign workers who entered on tourist visas in order to seek employment and overstayed. ${ }^{54}$ During this time, official immigration policy only sanctioned the migration of high-skilled labor. The 1988 Seoul Summer Olympics signaled a turning point when Korea first began to experience significant inflows of foreign labor, especially due to increased demand for labor in the construction-related sectors. ${ }^{55}$ The result was an increase in the number of undocumented workers that grew steadily between 1991 and 2001.56 By 1991, less than five years after the institution of democratic reforms on June 29, 1987, more than

50. Chulwoo Lee, 'Us' and 'Them' in Korean Law: The Creation, Accommodation and Exclusion of Outsiders in South Korea, in EAST ASIAN LAW: UNIVERSAL NORMS AND LOCAL Cultures 106, 120 (Arthur Rosett et al. eds., 2002).

51. JOHN LIE, ZaINICHI (KoREANS IN JAPAN): DIASPORIC NATIONALISM AND POSTCOLONIAL IDENTITY 4 (1993).

52. Asia PaCific Migration RESEARCh Network (APMRN), Migration Issues IN The ASIA PACIFIC: IsSUes PAPER From THE REPUBLIC of SouTH Korea (1997), available at http://www.unesco.org/most/apmrnw12.htm.

53. Lim, supra note 49 , at 426 .

54. See Timothy C. Lim, Will South Korea Follow the German Experience? Democracy, the Migratory Process, and the Prospects for Permanent Immigration in Korea, 32 KoR. STUD. 28, 33-36 (2008).

55. Lim, supra note 49 , at 426 .

56. Id. at 429 . 
45,000 migrant workers had entered Korea, an explosive increase from the previous decade. ${ }^{57}$

In response to the growing undocumented population, the Korean government instituted the Industrial and Technical Training System (ITTP), similar to the Japanese counterpart, the Industrial Trainee Program, which was intended to provide a government-administered system for overseeing and controlling the migration of unskilled foreign labor. ${ }^{58}$ Yet, the ITTP was criticized by civic activist groups because it denied foreign migrant workers the basic rights of Korea's tripartite labor laws: the rights of unionizing, collective bargaining, and protest. ${ }^{59}$ The second problem posed by the ITTP was the institutionalization of low wages, below that of minimum wage. ${ }^{60}$ Finally, by posing a one-year limit on the period of sojourn, the unintended consequence of the ITTP program was a significant increase in the number of undocumented workers. Despite reduced inflows of migrant workers during the 1997 Asian Financial Crisis and its immediate aftermath, foreign workers continued to arrive in Korea in ever-increasing numbers. Designed by migration experts, the EPS, which eventually replaced the ITTP (phased out in 2007), was introduced with great fanfare in 2004. Through the EPS, the Korean government grants basic labor rights, including pensions and health insurance to foreign workers, a standard that is on par with those granted to Korean workers as stipulated in the Labor Standard Act.61 The significance of this system was that it far exceeded the rights extended to foreign residents and workers in other industrialized countries.

The Korean government initially viewed the EPS as a long-term solution to labor shortages among the country's small and medium sized enterprises. ${ }^{62}$ The EPS, however, limits foreign workers to employment in only five industries: manufacturing, construction, agriculture and stockbreeding, fishing, and services. Further, it is only available to migrants from countries that have signed a bilateral agreement with Korea, such as the Philippines, Nepal, and Vietnam, among others. ${ }^{63} \mathrm{At}$ present, the maximum stay allotted by the visas (H-2 "working-visit" or E-9 "non-professional employment") issued under the EPS is five years,

57. See Erin Aeran Chung, Workers or Residents? Diverging Patterns of Immigrant Incorporation in Korea and Japan, 83 PAC. AFF. 675, 685 (2010).

58. Dong-Hoon Seol, Past and Present of Foreign Workers in Korea 1987-2000, 2 ASIA SOLIDARITY Q., no. 2, 2000, at 6 .

59. Id.

60. Id.

61. Legal Rights, EMP. PERMIT SYS. (2010), http://www.eps.go.kr/en/duty/duty_01.jsp.

62. See Lim, supra note 54 , at 35 .

63. 4 Major Social Insurance, EMP. PERMIT SYs. (2010), http://www.eps.go.kr/en/duty/ duty_03.jsp. 
but it remains contingent on whether workers are able to receive an extension of employment, which is largely the purview of the individual employers. ${ }^{64}$ Furthermore, foreign workers, including those hired through EPS, continue to face problems, such as nonpayment or late payment of wages, mistreatment, and abuse by employers.

Until the growing prevalence of international marriages in the mid2000 s, the vast majority of migrant labor to Korea was and continues to be male, although more female migrant labor has arrived as domestic workers and caregivers in recent years. ${ }^{65}$ Concurrent to labor shortages, Korea experienced a noted dearth of rural brides as marriage and fertility rates plummeted to the lowest among OECD countries. International marriage in Korea can be characterized by two stages: the first occurred during the early 1990s and involved mostly Chosunjok women, while the second has diversified both in its demographic and geographic composition. ${ }^{66}$

In the first wave, marriages were arranged between farmers and Chosunjok women through introductions by local governments, assemblies, and agricultural associations. ${ }^{67}$ From 1990 to 1999, there were 55,627 international marriages involving foreign wives and Korean husbands; of those, 37,171 were from China, most of them Chosunjok. ${ }^{68}$ Due to their resemblance to native Koreans, the early Chosunjok marriage migrants did not receive much widespread public attention, except for the increased incident of sham marriages among Chosunjok-Korean marriages. ${ }^{69}$

The second wave of marriage migration occurred after 2002, driven by the rise of commercialized international marriage agencies and the lack of government oversight over them, especially those that were located overseas. ${ }^{70}$ International marriages between foreign women and Korean men reached a peak in 2005, when they represented nearly fourteen percent of all marriages that took place that year. ${ }^{71}$ From 2001 to 2009 , the total number of marriage migrants in Korea grew nearly

64. Chung, supra note 57 , at 685 .

65. Hye-Kyung Lee, Gender, Migration and Civil Activism in South Korea, 12 AsIAN \& PAC. MigRaTION J. 127, 148-49 (2003).

66. Lee, supra note 8 , at 110-11.

67. Id. at 111 .

68. Id.

69. Id. at 114 .

70. Id. at 112 .

71. Korea IMmigr. Serv., Ftrst BASIC Plan FOR IMMIGRATION POLICY: 2008-2012, at 45 (2009), available at http:/www.scribd.com/doc/26660376/The-First-Basic-Plan-forImmigration-Policy-2008-2012-Ministry-of-Justice-Republic-of-Korea. 
five-fold from 25,182 to 125,087 , where nearly 88 percent were women. ${ }^{72}$ At the end of 2010 , the Korean government reported 141,654 marriage migrants residing in Korea. ${ }^{73}$

\section{REFORMING BLOOD-BASED NATIONAL MEMBERSHIP IN JAPAN AND KOREA}

Japan and Korea share similarities in patterns of immigration, driven by analogous demographic and economic trends and comprised of successive waves of coethnic and mostly unskilled laborers from Asia. Both countries have attempted to keep unskilled labor out despite sustained labor shortages, using "side door" practices to meet labor and demographic demands. ${ }^{74}$ In recent years, however, the Japanese and Korean governments passed unprecedented revisions to their respective nationality laws: the 2008 Supreme Court decision to grant Japanese nationality to children born out of wedlock to a foreign mother and Japanese father in Japan and the 2010 multiple-nationality bill passed by the National Assembly, which permits dual nationality for marriage migrants, among other foreign groups. ${ }^{75}$ These revisions represent both states' attempts to incorporate multicultural families into the polity by divorcing nationality from monocultural ideology. Despite these convergences, however, the government responses to reforming bloodbased national membership have diverged in scope and in magnitude, reflecting different conceptions of and orientations toward multiculturalism and diversity.

\section{A. Mixed-Blood Nationals and Ethnic Japanese Foreigners in Japan}

Since the enactment of the Nationality Law in 1950, there have been no major changes to citizenship attribution criteria in Japan except for two pertaining to bicultural children: the 1984 and 2008 revisions. With the 1984 revision of the Nationality Law following Japan's ratification of the Convention on the Elimination of All Forms of

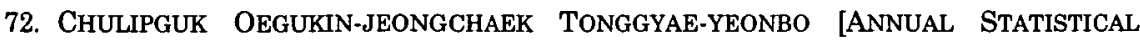
REPORT FOR POLICIES ON IMMIGRATION AND FOREIGNERS], supra note 7, at 695-96.

73. Id. at 24 .

74. Tsuda \& Cornelius, supra note 44 , at $452-57$.

75. Saikō Saibansho [Sup. Ct.] June 4, 2008, 2006 (Gyo-Tsu) no. 135, 62 http:/www.courts.go.jp/english/judgments/text/2008.06.04-2006.-Gyo-Tsu-.No..135111255.html (Japan); Gukjeok beob [Nationality Act], Act. No. 8892, Mar. 14, 2008, amended by Act. No. 10275, May 4, 2010 (S. Kor.), available at http://likms.assembly.go.kr/law/ jsp/law/LawThree.jsp?WORK_TYPE=LAW_THREE\&LAW_ID=A1295\&PROM_NO=10275\& PROM_DT=20100504. 
Discrimination against Women, children of international marriages are eligible to gain Japanese nationality either through their father or mother's nationality. ${ }^{76}$ Until 2008, however, children born out of wedlock to a foreign mother and Japanese father could not gain Japanese nationality automatically unless paternity could be determined at the time of the child's birth. ${ }^{77}$ This condition posed a problem for a significant fraction of bicultural children in Japan. Although international marriages between native Japanese men and foreign women from the 1980s resulted in the birth of numerous bicultural children eligible for Japanese nationality, extramarital sexual liaisons and divorces created a growing population of bicultural children without Japanese nationality. The latter population was largely the product of the second wave of immigration to Japan, specifically, female migrants who entered Japan as "entertainers" and their encounters with Japanese men both on and off the job. Unlike Korea, divorce rates in Japan surpassed marriage rates between international couples by the time that the landmark 2008 court case forced the government to revise the Nationality Law. ${ }^{78}$

Similar to the circumstances of the earlier 1984 revision to the Nationality Law, the primary problem of the 2008 case centered on the unfair application of jus sanguinis, as opposed to the liberalization of the Nationality Law (to include elements of jus soli). ${ }^{79}$ The ten plaintiffs in the case were born out of wedlock to Filipino mothers and Japanese fathers who had acknowledged their paternity after the children were born. As Nobue Suzuki details in her rich ethnographic study of the plaintiffs in the case, Japan's Nationality Law had, until 2008, applied a "fetus recognition" (taiji ninchi) system to children born out of wedlock that required Japanese fathers to acknowledge their paternity while the children were fetuses. ${ }^{80}$ On June 4, 2008, the Supreme Court ruled the marriage and legitimation requirements for Japanese nationality discriminatory and unconstitutional, prompting the aforementioned revision to the Nationality Law. ${ }^{81}$

76. Koku seki hō [The Nationality Law], Law No. 147 of 1950, art. 2, para. 1 (Japan), amended by Law No. 268 of 1952, Law No. 45 of 1984, Law No. 89 of 1993, Law No. 147 of 2004, Law No. 88 of 2008); Convention on the Elimination of all Forms of Discrimination against Women, Dec. 18, 1979, 1249 U.N.T.S. 13.

77. Nobue Suzuki, Outlawed Children: Japanese Filipino Children, Legal Defiance and Ambivalent Citizenships, 83 PAC. AFF. 37, 43.44 (2010).

78. Saikō Saibansho [Sup. Ct.] June 4, 2008, 2006 (Gyo-Tsu) no. 135, 62 SAIKō SAIBANSHO MINJI HANREISHŪ [MINSHŪ], supra note 75.

79. Id.

80. Suzuki, supra note 77 , at 31,37 .

81. Saikō Saibansho [Sup. Ct.] June 4, 2008, 2006 (Gyo-Tsu) no. 135, 62 SAIKō SAIBANSHO MINJI HANREISHŪ [MINSHŪ], supra note 75. 
The 2008 Supreme Court ruling was significant because it applied the nondiscrimination principle to the nationality issue, thereby expanding eligibility for Japanese nationality to not only those born to married couples or, at the very least, a Japanese mother, but also to those who could demonstrate evidence of a direct blood connection to a Japanese national.82 Combined with the 1984 revision, this reform fundamentally challenged Japanese nationality laws that were based on ethnic purity, patrilineal descent, and the institution of marriage. The 1984 and 2008 reforms to the Nationality Law highlighted the need to adjust the laws for those with "mixed" blood, specifically those without Japanese fathers in the first instance and those born out of wedlock in the second.

It should be noted, however, that the Nationality Law was not revised to allow ethnic Japanese (Nikkei) immigrants automatic, or at least simplified, access to Japanese nationality. On the contrary, the two reforms, inadvertently perhaps, widen the gap between foreigners and Japanese nationals, regardless of blood ties, and further constrict the definition of Japanese national identity. While opening up the possibility for a multiethnic conception of Japanese nationality, the reforms, which were directed at children of Japanese nationals, make the link between consanguinity and nationality more literal by making the passive transmittal of blood the basis for granting Japanese nationality.

Because blood ties alone do not guarantee Japanese nationality for coethnic immigrants, however, the application of descent to nationality remains limited and inconsistent. In Japan, Nikkei immigrants constitute a special category of foreigners who, unlike most immigrants, automatically qualify for visas that allow for unrestricted economic activities and continued residence in Japan for up to three years, which they can renew an indefinite number of times. While their Japanese descent makes Nikkei immigrants the exception to Japan's otherwise closed-door immigration policies, it does not give them clear pathways to Japanese citizenship. Like all other foreigners, ethnic Japanese immigrants must undergo the process of naturalization in order to become Japanese nationals.

The ways that the Nikkei have been incorporated into public debates on Japan's "multicultural" society, moreover, privilege nationality over ethnicity. Since the late 1990s, local governments, NGOs, the Japanese media, and even some bureaucrats and politicians have made references to Japan's "multicultural" society. ${ }^{83}$ In 2006 , the

82. Id.

83. See Roger Pulvers, Barriers to Multiculturalism Are as Low as They've Ever Been in Japan, JAPAN TIMES (Aug. 14, 2011), http://www.japantimes.co.jp/text/fl20110814rp.html. 
Ministry of Internal Affairs and Communications (MIC) announced Japan's first comprehensive framework for immigrant incorporation in the form of a "multicultural coexistence" (tabunka kyōsei) promotion plan that calls for all of Japan's prefectures and major cities to devise plans for "multicultural community building." 84 The guidelines provided in the MIC plan focus on four broad tasks: support for intercultural communication, assistance in everyday life, the development of a "multicultural coexistence" community, and promotion of "multicultural coexistence" policies. ${ }^{85}$ Local governments with relatively large proportions of foreign residents in their communities have undertaken these tasks by publishing multilingual pamphlets, providing Japanese language classes, offering free legal counseling, and holding "multicultural" events and festivals, among other things. ${ }^{86}$

In communities with relatively large numbers of Latin American residents, Nikkei immigrants have been at the center of debates on the dangers or benefits of Japan's growing social diversity based not on their ethnicities but on their Brazilian or Peruvian nationalities. ${ }^{87}$ "Multicultural" events and festivals in such communities often entail the celebration of "Latin" culture with Nikkei immigrants at the center, such as the annual samba carnival in Oizumi City, a small industrial town in Gumma Prefecture where over 10 percent of the population is Brazilian. ${ }^{88}$ Such "multicultural" celebrations highlight how distinct Japanese nationals are even from other ethnic Japanese. As one Nikkei Brazilian recounts:

So my friends [in Brazil] used to call me china. My nickname was china. I mean, I grew up like that ... [hearing] China, china ... [China] is not Brazilian right? The impression you have is that you're never going to be Brazilian by your appearance. And once you

84. Ministry of Internal Aff. \& Communic'ns, Tabunka kyōsei suisin puroguramu [Multicultural Coexistence Promotion in Local Communities] (2006).

85. Chung, supra note 23, at 684 .

86. See generally Kashiwazaki Chikako, Local Government and Resident Foreigners: $A$ Changing Relationship, in JAPAN'S ROAD TO PLURALISM: TRANSFORMING LOCAL COMMUNITIES IN THE Global ERA 63 (Furukawa Shun'ichi \& Menju Toshihiro eds., 2002).

87. See Norimitsu Onishi, An Enclave of Brazilians Is Testing Insular Japan, N.Y. TIMES (Nov. 2, 2008), http:/www.nytimes.com/2008/11/02/world/asia/ 02japan.html?pagewanted=all; see generally TAKEYUKI TSUDA, STRANGERS IN THE ETHNIC HOMELAND: JAPANESE BRAZILIAN RETURN MIGRATION IN TRANSNATIONAL PERSPECTIVE (2003).

88. Yasuda Naoko, Brazilian Community at Oizumi in Japan, ALT. VIEws (Aug. 10, 2007), http://en.parc-jp.org/news/features/multicultural_society/sub/brazilian-communityat-oizumi-in-japan; see also Daniela de Carvalho, Nikkei Communities in Japan, in GLOBAL JAPAN: THE EXPERIENCE OF JAPAN'S NEW IMMIGRANTS AND OVERSEAS COMMUNITIES 195 (Roger Goodman et al. eds., 2003). 
arrive in Japan, well [you're called] Brazilian (burajirujin). ${ }^{89}$

What is striking about "multicultural coexistence" programs and discourse in Japan is the absence of multiethnic Japanese individuals and families. The fact that naturalized citizens of foreign descent and bicultural children do not figure prominently in Japan's version of "multiculturalism" underlines the degree to which Japan's multiethnic population, including both new and old immigrant groups, remains disaggregated from Japan's nationality-based multicultural discourse. Moreover, the contrasting approaches to incorporating "multiethnic children" as Japanese nationals, on the one hand, and ethnic Japanese foreigners as part of Japan's "multicultural society," on the other, highlights the ways that blood, nationality, and citizenship are increasingly becoming disaggregated in Japan.

\section{B. Targeted Multiculturalism and Multicultural Families in Korea}

Since its enactment in 1948, the Korean Nationality Law has undergone two major revisions. The first occurred in 1997 to allow bicultural children to gain Korean nationality either through their father or mother. Prior to the 1997 amendment, children of international marriages were eligible to gain nationality only if their father was a Korean national.90 The second major revision took place in April 2010, when the National Assembly reformed the Nationality Law to allow multiple nationality (boksugukjeok). ${ }^{91}$ Under this law, the following categories of persons are eligible to hold multiple nationalities, under the condition that they take an oath not to exercise their rights as a foreign national while in Korea: (1) highly skilled foreigners with "exceptional talent" in the fields of culture and arts, athletics, management, specialized technical expertise as evaluated by a committee within the Ministry of Justice; (2) Koreans who gained dual

89. Interview with Anonymous, in Kawasaki, Japan (Menandro Gomes trans., July 21, 2010).

90. Lee, supra note 8 , at 112-13.

91. The term "dual national" is changed to "multiple national." Gukjeok beob [Nationality Act], Act. No. 8892, art. 4. Because of the negative connotation that it holds regarding one's loyalty to the country, the term "dual nationality" (ijoonggukjeok) is avoided in the legal and political discourse in Korea. Instead, the term "multiple nationality" has been adopted. See Duck-hwa Hong, ijunggukjeok $\rightarrow$ boksugukjeok euro bakkwin baegyeong /Context Behind the Change from Dual $\rightarrow$ Multiple Nationality, YONHAP NEWS (Sept. 2, 2009), http://www.yonhapnews.co.kr/bulletin/2009/09/02/0200000000AKR20090902159100069.HT ML; Kang Shin-who, Lawyers' Group Calls for Dual Nationality, KoREA TIMEs (Nov. 10, 2007, 6:06 PM), http://www.koreatimes.co.kr/www/news/nation/2011/04/117_11746.html. 
citizenship at birth, by being born in a country that grants birthright citizenship, and have fulfilled military service;92 (3) overseas Koreans over sixty-five years of age; and (4) marriage migrants who are presently married to a Korean national. ${ }^{93}$

The multiple-nationality bill was part of a larger set of reforms to immigration and citizenship policies enacted since the mid-2000s in response to the rapidly expanding foreign resident population.94 For many years, Korean policymakers had debated the idea of introducing dual nationality, particularly since the passage of the Overseas Korean Act in 1999, which grants employment and other quasi-dual citizenship rights to certain groups in the Korean diaspora. ${ }^{95}$ The greatest hurdle facing the acceptance of dual nationality had been the issue of military conscription, one of the most politicized obligations of Korean citizenship for men, and related concerns that too many people would invoke foreign citizenship in order to evade military service. Several high-profile cases of draft evasion by the sons of celebrities and of the political elite who claimed foreign citizenship made dual nationality a tricky political issue that few politicians were willing to address.

Growing concerns about demographic trends, the need to more aggressively recruit attractive immigrants, and the social problems facing multicultural families, however, prompted officials and policymakers to rekindle the debate on dual and multiple nationality in

92. Koreans who lost their citizenship by acquiring a foreign one are eligible to reacquire their citizenship, provided (in the case of men) that they have fulfilled military duty. Dual Citizenship is the Way of the Future, CHosuniLBo (Oct. 20, 2009, 1:08 PM), http://english.chosun.com/site/data/html_dir/2009/10/20/2009102000811.html.

93. There are some notable exclusions to the categories of eligible groups: (1) native-born Chinese immigrants, many of whom are now third-generation and beyond; (2) marriage migrants who have divorced and are without children born to a Korean spouse; and (3) children who gain birthright citizenship in other countries (so-called "anchor babies") in which their parents did not reside for more than six months. Lee Tae-hoon, Dual Citizenship to Be Allowed, KOREA TTMES (Apr. 21, 2010, 8:02 PM), http://www.koreatimes.co.kr/ www/news/nation/2011/04/116_64629.html.

94. Dual Citizenship on the Cards Again, CHosunilbo, (Oct. 19 2009, 12:57 PM), http://english.chosun.com/site/data/html_dir/2009/10/19/2009101900824.html.

95. Initially the Overseas Korean Act did not apply to Koreans who never held South Korean citizenship, meaning those émigrés and their descendants who left Korea before 1948, the year of the founding of the Republic of Korea. This stipulation essentially excluded most ethnic Koreans from China and the former Soviet Union. In 2004, the Act was revised to include ethnic Koreans from China, albeit with restrictions, after the Constitutional Court ruled in 2001 that the act was discriminatory. Jung-Sun Park \& Paul Y. Chang, Contention in the Construction of a Global Korean Community: The Case of the Overseas Korean Act, 10 J. KoR. STUD. 1, 2, 4 (2005). 
2008. ${ }^{96}$ In these debates, civic activists and migrant advocacy groups persistently pressured policymakers to include marriage migrants as an eligible group because of the legal vulnerabilities they face as migrants seeking naturalization. ${ }^{97}$ Despite simplified naturalization procedures granted to marriage migrants, the entire process of acquiring Korean nationality can take from three to six years after marriage due to continuous residency requirements. ${ }^{98}$ Between applying for naturalization and acquiring citizenship, the legal status of marriage migrants who remain on spousal visas depends on the willingness of the husband to sponsor and verify his spouse's marital status, which must be done annually with each visa renewal. One ethnic Korean immigrant from China describes her frustration with having to rely on her husband for naturalization, stating, "it's been a long time since I was eligible for naturalization, but my husband wouldn't apply for me. And they [immigration officials] were very suspicious of why it took me so long to submit my papers." 99 With growing divorce rates among international marriages, often due to abuse and violence, many marriage migrants and the children they have brought with them from previous marriages have ended up stateless or undocumented, and thus, at high risk for deportation. 100

While the inclusion of marriage migrants in the multiple-nationality bill may signal the government's acceptance of the group as desirable immigrants, it also represents the government's attempt to manage Korea's rapidly growing diversity by situating "multicultural families" as the core agents and recipients of targeted incorporation policies. In

96. See Learning Times, Dual Citizenship: Government Mulls Policy Change to Prevent Brain Drain, KOREA TIMES (Oct. 31, 2007), http://www.koreatimes.co.kr/koreatime_admin/ LT/common/nview.asp?idx $=645 \&$ nmode $=2$.

97. Initial discussion of granting dual nationality extended to highly skilled professionals and overseas adoptees. However, in public forums hosted by the Ministry of Justice, policymakers and civic activists raised the opinion that marriage migrants, overseas Koreans, and Chinese-Koreans should be included as potential holders of multiple nationality. The Ministry of Justice then conducted a public survey regarding public attitudes toward the granting of multiple nationality to various groups. This newspaper reports that 37.4 percent of those surveyed responded positively to marriage migrants as holders of multiple nationality. Duck-hwa Hong, Boksugukjeok heoyong jindan [A Diagnosis of Multiple Nationality], YoNHAP NEWS (Sept. 13, 2009), http:/www.yonhapnews.co.kr/bulletin/2009/09/06/0200000000AKR20090906001800069.HT ML.

98. At present, marriage migrants are required to reside in Korea for two full consecutive years in order to be eligible to apply for naturalization. Simplified Naturalization (Marriage), HI KOREA (Oct. 16, 2008), http://www.hikorea.go.kr/pt/InfoDetailR_kr.pt.

99. Interview with Kyung-Ae Kim, in Seoul, S. Kor. (June 18, 2010).

100. In Seop Chung et al., The Treatment of Stateless Persons and the Reduction of Statelessness: Policy Suggestions for the Republic of Korea, KOREA REV. INT'L STUD. 20-22 (2009). 
2006, the focus of immigration and immigrant integration policies visibly shifted from migrant workers to marriage migrants when the Roh Moo-Hyun government (2003-2008) announced the "Grand Plan," a comprehensive policy framework aimed at the integration of marriage migrants and the attainment of a "multicultural society."101

There were two main reasons for the policy shift. First, the passage of the EPS in 2003 and the successive phasing out of the ITTP mitigated the politicization of the migrant-worker issue, providing a political opportunity for the government to direct its attention elsewhere. Despite the controversial aspects mentioned above, the EPS was perceived as a compromise between migrant worker activists, who wanted greater recognition of migrant workers' rights, and government officials, who sought to maintain control over the migrant worker system through strict regulations. ${ }^{102}$

Second, and perhaps more importantly, the advocacy efforts of civil society actors demonstrated to policymakers that the myriad social issues surrounding marriage migrants-high poverty rates, domestic violence, and divorce rates-merited full and immediate attention. ${ }^{103}$ Marriage migrants were not the only concern of future-oriented government officials; they recognized that the difficulties experienced by mixed-blood, "multicultural" children in adapting to the Korean educational system posed a considerable challenge to social cohesion in the present and in the future. As a result, not only marriage migrants and their children, but "multicultural families" (damunhwa gajeong), have been targets of the policy spotlight as the vanguard of the new "multiculturalism."

This "targeted multiculturalism," however, has been accompanied by the increasingly rigid exclusion of other migrant groups-migrant workers and ethnic return migrants, particularly from China. ${ }^{104}$ While marriage migrants and multicultural families have been singled out as

101. The "Grand Plan" is a master policy framework for coordinating integration policies among the major ministries, including the Ministry of Gender Equality and Family, Justice, Labor, Social Welfare and Health, and their respective local divisions. Lee, supra note 8 , at 116. Furthermore, in the same year, the government passed two bills: the Plan for Social Integration of Mixed-bloods and Migrants and the Plan for Social Integration of Marriage Immigrants. These forerunners laid the groundwork for the far-reaching Basic Act on the Treatment of Foreigners in Korea in 2007. This Act set distinct guidelines for integrating marriage migrants into society, among other categories of immigrant populations, such as overseas Koreans and migrant workers. Chung, supra note 23, at $682-83,687$.

102. Lim, supra note 54 , at $35-36$.

103. Lee, supra note 8 , at 115.

104. See Erin Aeran Chung, Korea and Japan's Multicultural Models for Immigrant Incorporation, 41 KOREA OBSERVER 649, 670 (2010). 
a "model minority" group, migrant workers continue to be denied the right to permanent settlement. ${ }^{105}$ The status of marriage migrants themselves as potential citizens is often contingent on the female migrant's capacity to fulfill her assigned roles in the family as wife, mother, and daughter-in-law, thereby solidifying the links between marriage, family, and national membership.

The inclusion of marriage migrants in the multiple-nationality bill attests to the role of international marriages in shaping and transforming conceptions of national membership, identity, and citizenship based on monocultural principles in Korea. As stipulated by the new Nationality Law, marriage migrants who have been granted the privilege of membership on the basis of lawful marriage to a Korean national are considered equals to coethnic return migrants of the Korean diaspora. ${ }^{106}$ On a more practical level, by allowing marriage migrants to retain their native nationalities, Korean policymakers aimed to encourage higher rates of naturalization, which, in Tomas Hammar's words, is "the last step in a long process of integration into the country."107

\section{CONCLUSION}

Korea and Japan have previously been identified as recent countries of immigration with exclusionary immigration policies and ethnic citizenship regimes. However, such categorizations cannot adequately explain the recent changes to membership criteria as reflected in recent reforms to both countries' nationality laws. These reforms suggest a breakdown of monocultural membership as the acquisition of citizenship becomes divorced from ethnocultural homogeneity. Such ongoing transformations then raise questions about the heuristic value of the ethnic-civic dichotomy, a concept used to generalize national conceptions of membership and citizenship. Rather, as this Article has shown, the analytical lens should be placed on the contested fluidity of membership that lies in the interactions between state and social actors.

The divergent ways that Japan and Korea have attempted to incorporate different immigrant groups into their societies reflect each country's attempt to absorb greater social diversity while maintaining social stability and democratic accountability. Although both countries

105. See generally Byoungha Lee, The Development of Korea's Immigration Policies: Security, Accumulation, Fairness, and Institutional Legitimacy, 40 KOREA OBSERVER 763, 791 (2009).

106. See Gukjeok beob [Nationality Act], Act. No. 8892, art. 13.

107. Tomas Hammar, Dual Citizenship and Political Integration, 19 INT'L MIGRATION REV. 438, 448 (1985). 
have applied the language of "multiculturalism" in their frameworks for incorporating immigrants, neither has embraced in full the prospect of cultural pluralism. On the contrary, each country's so-called multicultural framework highlights the tensions between each society's acknowledgement of the swelling ranks of immigrants within their borders and their uneasiness with permanent immigrant settlement. In both cases, gendered migration has unraveled the core of monocultural conceptions of both the family and the nation, forcing the Japanese and Korean states to redefine the meaning, terms, and rights of political and social membership. 
